\title{
PENGEMBANGAN SOAL HIGHER ORDER THINKING SKILL (HOTS) MATERI BILANGAN DI SEKOLAH MENENGAH PERTAMA
}

\author{
Sitri Cayani, Mawardi Lubis, Poni Saltifa ${ }^{*}$ \\ Program Studi Tadris Matematika, IAIN Bengkulu \\ *Email korespondensi: saltifa14071991@gmail.com
}

\begin{abstract}
ABSTRAK
Tujuan Penelitian ini yaitu mengembangkan soal HOTS materi bilangan kelas VIII di SMP Negeri 1 Kota Bengkulu yang valid dan praktis. Jenis penelitian yang digunakan dalam penelitian ini adalah Research and Development (R\&D) dengan pendekatan kualitatif dan kuantitatif. Model pengembangan yang digunakan dalam penelitian ini adalah model Martin Tessmer yang terdiri dari tahap preliminary, tahap self evaluation (analisis kurikulum, peserta didik, materi, dan desain), tahap prototyping (validasi, evaluasi, dan revisi) yang meliputi expert review, one-to-one dan small group. Hasil pengembangan soal HOTS materi bilangan kelas VIII di SMP Negeri 1 Kota Bengkulu diperoleh nilai validitas dari 3 orang validator sebesar 3,73 yang berarti soal tes HOTS ini berada pada criteria sangat valid selanjutnya soal tes HOTS yang sudah peneliti kembangkan diperoleh nilai kepraktisan pada tahap small group (6 orang peserta didik) sebesar $93,75 \%$ berada pada kriteria sangat praktis.
\end{abstract}

Kata kunci: pengembangan, soal HOTS, materi bilangan.

\begin{abstract}
The purpose of this study was to HOTS questions for class VIII numbers in SMP Negeri 1 Bengkulu City. The type of research used in this research is R \& D / Research and Development with qualitative and quantitative approaches. The development model used in this research is Martin Tessmer's model which consists of the preliminary stage, the self-evaluation stage (curriculum analysis, students, materials, and design), the prototyping stage (validation, evaluation, and revision) which includes an expert review, one- to-one and small groups. The results of the development of HOTS questions for grade VIII in SMP Negeri 1 Bengkulu City obtained the validity value of 3 validators of 3.73 which means that the HOTS test questions are in very valid criteria, then the HOTS test questions that the researcher have developed obtained practicality values at the small stage group (6 students) of $93.75 \%$ are in very practical criteria.
\end{abstract}

Keywords: development, HOTS questions, number material.

\section{PENDAHULUAN}

Matematika menjadi salah satu mata pelajaran yang kurang disukai oleh sebagian peserta didik yang berdampak pada semangat dan motivasi untuk mempelajarinya sangat sedikit dan berakibat pada hasil belajar siswa yang kurang dalam memenuhi kriteria kelulusan 
minimum (KKM). Padahal menurut Kusumah (2018), program pendidikan matematika merupakan salah satu upaya untuk memenuhi tujuan mencerdaskan kehidupan masyarakat bangsa dan membangun manusia Indonesia seutuhnya. Hal ini tentunya menjadi masalah yang perlu menjadi fokus untuk segera diselesaikan.

Dalam mengatasi hambatan belajar siswa diperlukan adanya keahlian khusus yang harus dimiliki pendidik agar mampu menyesuaikan kompetensi mereka sesuai dengan tuntutan zaman, kemajuan sains, dan teknologi. Lebih lanjut Mulyadin (2018) mengungkapkan bahwa sebagai salah satu sumber ilmu, peran guru dalam merancang pembelajaran yang menarik dan mudah diterima siswa merupakan salah satu kunci dalam proses pembelajaran.

Di era revolusi industri 4.0, kompleksitas dan semakin ketatnya persaingan dunia kerja memberikan tuntutan pada program pendidikan matematika untuk mampu mengembangkan lagi proses melalui kegiatan pembelajaran yang mampu menumbuhkembangkan kemampuan beripikir yang tidak hanya terpaku pada penilaian hasil pembelajaran (Sowanto dkk, 2019). Adapun aspek atau domain kognitif adalah ranah yang mencakup kegiatan mental (otak). Menurut Bloom, segala upaya yang menyangkut otak adalah termasuk dalam ranah kognitif. Dalam ranah kognitif terdapat enam jenjang proses berpikir, mulai jenjang terendah sampai dengan jenjang yang paling tinggi. Keenam jenjang yang dimaksud adalah pengetahuan (knowledge), pemahaman (comprehension), penerapan (application), analisis (analysis), sintesis (shythesis), dan penilaian (evaluation) (Nursalam, 2017). Lebih lanjut Ramos, Dolipas, dan Villamor dalam Jailani, Sugiman, dan Apino (2017) mengungkapkan “In relation to the cognitive dimension, the HOTS is characterized by the three higher levels in Bloom's taxonomy namely analysis, evaluation and creation".

Tingkatan pertama Taksonomi Bloom Revisi yaitu mengingat yang disebut dengan LOTS (Lower Order Thinking Skills), dua tingkatan selanjutnya yaitu memahami dan mengaplikasi disebut dengan MOTS (Middle Order Thinking), sedangkan tiga tingkatan berikutnya yaitu menganalisis, mengevaluasi, dan menciptakan disebut HOTS (Higher Order Thinking Skills) (Anderson \& Krathwohl; Widana dalam Wulandari dan Duskri, 2020). Berdasarkan taksonomi bloom tersebut, maka kemampuan peserta didik dapat diklasifikasikan menjadi dua, yaitu tingkat tinggi dan tingkat rendah. Kemampuan tingkat rendah terdiri atas pengetahuan, pemahaman dan aplikasi, sedangkan kemampuan tingkat tinggi meliputi analisis, sintesis, evaluasi dan kreativitas. Dengan demikian, kegiatan peserta 
didik dalam menghafal termasuk kemampuan tingkat rendah. Dilihat dari cara berpikir, maka kemampuan berpikir tingkat tinggi dibagi menjadi dua, yaitu berpikir kritis dan berpikir kreatif.

Berfikir kreatif adalah kemampuan melakukan generalisasi dengan menggabungkan, mengubah atau mengulang kembali keberadaan ide-ide tersebut. Kemampuan berpikir kritis merupakan kemampuan memberikan rasionalisasi terhadap sesuatu dan mampu memberikan penilaian terhadap sesuatu tersebut. Rendahnya kemampuan peserta didik dalam berpikir, bahkan hanya dapat menghafal, tidak terlepas dari kebiasaan guru dalam melakukan evaluasi ataupenilaian yang hanya mengukur tingkat kemampuan yang rendah saja melalui paper and pencil tes. Peserta didik tidak akan mempunyai kemampuan berpikir tingkat tinggi jika tidak diberikan kesempatan untuk mengembangkannya dan tidak diarahkan untuk itu (Arifin, 2016)

Evaluasi atau penilaian yang biasanya dilakukan oleh guru juga hanya mengukur kemampuan berpikir tingkat rendah (Lower Order Thinking) misalnya menghafal rumus matematika untuk menyelesaikan soal-soal matematika tanpa pemahaman konsep sehingga kemampuan berpikir peserta didik tidak dapat berkembang. Permasalahan yang terjadi di sekolah, soal-soal cenderung lebih banyak menguji aspek ingatan yang kurang melatih keterampilan berpikir tingkat tinggi peserta didik. Kemampuan berpikir anak Indonesia secara ilmiah dianggap masih rendah dilihat dari hasil penelitian yang dilakukan oleh Rahayu, dkk (2008) diketahui bahwa salah satu faktor penyebabnya antara lain karena peserta didik di Indonesia kurang terlatih dalam menyelesaikan soal-soal yang mengukur (Higher Order Thinking Skiil) HOTS, dan masalah yang dihadapi oleh guru adalah kemampuan guru dalam mengembangkan instrumen asessmen HOTS masih kurang dan belum tersedianya instrumen asessmen yang didesain khusus untuk melatih HOTS, sehingga perlu dikembangkan instrumen asessmen HOTS.

Pengembangan keterampilan berpikir tingkat tinggi peserta didik akan menghasilkan kemahiran peserta didik dalam strategi pemecahan masalah menjadi baik, tingkat keyakinan peserta didik dalam matematika meningkat, dan prestasi belajar peserta didik pada masalah non-rutin yang menuntut keterampilan berpikir tingkat tinggi meningkat. Pengembangan Higher Order Thinking Skills (HOTS) dalam pembelajaran merupakan salah satu wujud pengimplementasian kurikulum 2013, sehingga kegiatan pembelajaran maupun evaluasi yang dilakukan hendaknya berorientasi pada HOTS (Badjeber dan Purwaningrum, 2018). 
Selama enam tahun terakhir ini Kurikulum 2013 telah diterapkan untuk semua jenjang pendidikan, namun permasalahannya sebagian besar sekolah belum sepenuhnya menerapkan proses pembelajaran sebagaimana yang diharapkan dalam kurikulum tersebut. Hal ini sesuai yang diungkapkan Yokri dan Saltifa (2020)bahwa kenyataan di lapangan menunjukkan belum sepenuhnya pembelajaran matematika di sekolah khususnya di sekolah menengah pertama (SMP) mendukung pengembangan kemampuan pemecahan masalah sehingga proses pemilihan strategi pemecahan masalah yang digunakan peserta didik juga belum tepat dan hanya mampu menggunakan satu strategi penyelesaian masalah. Contohnya dalam hal melakukan proses penilaian pembelajaran peserta didik pada ranah pengetahuan dengan memberikan soal-soal latihan, guru masih cenderung memberikan soal yang hanya menguji aspek ingatan dan kurang melatih keterampilan berpikir tingkat tinggi peserta didik, terutama pada muatan pelajaran matematika. Hal ini dikarenakan kemampuan guru dalam mengembangkan soal HOTS masih sangat kurang.

Berdasarkan observasi awal di SMP Negeri 1 kota Bengkulu diperoleh bahwa tes hasil belajar matematika peserta didik masih rendah pada materi bilangan. Salah satu faktornya adalah instrumen tes yang diberikan oleh guru kepada peserta didiknya hanya menguji pengetahuan, pemahaman yang termasuk dalam kategori menguji kemampuan berpikir tingkat rendah (Low Order Thinking Skill) dan penerapan. Sedangkan buku pembelajaran kurikulum 2013 sudah terdapat beberapa soal-soal yang mengukur kemampuan tingkat tinggi (Higher Order Thinking Skill). Jadi guru jarang mengembangkan instrumen tes dalam bentuk tes HOTS dan belum ada tes yang didesain khusus untuk melatih HOTS sehingga peserta didik kurang terlatih untuk mengerjakan soal-soal yang mengukur kemampuan berpikir tingkat tingginya.

Berdasarkan uraian masalah di atas maka dilakukan penelitian Pengembangan Soal Higher Order Thinking Skill (HOTS) Materi Bilangan di Sekolah Menengah Pertama. Adapun tujuan penelitian ini yaitu untuk mengetahui pengembangan soal HOTS materi bilangan kelas VIII di SMP Negeri 1 Kota Bengkulu yang valid.

\section{METODE PENELITIAN}

Jenis penelitian yang digunakan dalam penelitian ini adalah $\mathrm{R} \& \mathrm{D} /$ Research and Development dengan pendekatan kualitatif dan kuantitatif. Model pengembangan yang digunakan dalam penelitian ini adalah model Martin Tessmer (1993). Prosedur pengembangan 
(research and development) terdiri dari beberapa langkah, yaitu: Tahap preliminary, tahap self evaluation (analisis kurikulum, materi, peserta didik, dan desain), dan tahap prototyping (validasi, evaluasi dan revisi) yang meliputi expert review. Berikut langlah-langkah yang akan dilakukan oleh peneliti adalah sebagai berikut:

\section{Tahap Preliminary}

Pada tahap Preliminary akan dilakukan pengkajian terhadap beberapa sumber referensi yang berkaitan dengan penelitian ini. Setelah beberapa teori dan informasi sudah terkumpul, akan dilakukan kegiatan penentuan tempat dan subjek uji coba dengan cara menghubungi kepala sekolah dan guru mata pelajaran matematika di sekolah yang akan dijadikan lokasi penelitian serta mengadakan persiapan-persiapan lainnya, seperti mengatur jadwal penelitian dan prosedur kerjasama dengan guru kelas yang akan dijadikan sebagai tempat penelitian.

\section{Tahap Self Evaluation}

Pada tahap self evaluation dilakukan penilaian oleh diri sendiri terhadap desain instrumen Higher Order Thinking Skill (HOTS) yang akan dibuat oleh peneliti. Tahap ini dibagi menjadi 2 tahap yaitu analisis dan desain.

\section{Analisis}

1. Analisis Kurikulum

Pada langkah ini dilakukan telaah terhadap kurikulum matematika, literatur, dan tantangan serta tuntutan masa depan, sehingga diperoleh instrumen tes yang dapat mengukur kemampuan higher order thinking skill pada materi bilangan.

2. Analisis Peserta didik

Kegiatan yang dilakukan pada langkah ini adalah menggali informasi tentang jumlah peserta didik dan karakteristik peserta didik yang sesuai dengan rancangan dan pengembangan instrumen tes.

\section{Analisis Materi}

Kegiatan analisis materi ditujukan untuk mengidentifikasi, merinci, dan menyusun secara sistematis materi-materi utama yang akan dipelajari peserta didik berdasarkan analisis kurikulum. Analisis ini membantu dalam mengidentifikasi materi-materi utama yang akan digunakan sebagai rambu-rambu pengembangan instrumen tes. 


\section{Desain}

Kegiatan yang dilakukan pada tahap desain ini, peneliti mendesain kisi-kisi soal pada instrumen tes, soal-soal instrumen tes higher order thining skill (HOTS) dan kunci jawaban instrumen tes. Desain produk ini sebagai prototype. Masing-masing prototype fokus pada tiga karakteristik yaitu: konten, konstruks dan bahasa. Uraian ketiga karakteristik tersebut dapat dilihat pada tabel berikut:

Tabel 1. Karakterisitik Prototype

\begin{tabular}{ll}
\hline Konten & a. Kesesuaian dengan materi bilang SMP kelas VIII \\
& b. Kejelasan maksud soal \\
\hline Konstruk & a. Soal sesuai dengan teori yang mendukung dan indikator: \\
& b. Bertipe penemuan hubungan berbagai representasi dari konsep, \\
& penerapan matematika di bidang lain, dan penerapan \\
& matematika di kehidupan sehari-hari. \\
& c. Memiliki solusi atau strategi penyelesaian lebih dari satu. \\
& d. Sesuai dengan level peserta didik kelas VIII SMP \\
& a. Sesuai dengan EYD \\
& b. Soal tidak mengandung penafsiran ganda \\
& c. Kalimat soal komutatif, menggunakan bahasa yang sederhana, \\
& dan mudah diapahami peserta didik. \\
\hline
\end{tabular}

\section{Tahap Prototyping (Validasi, Evaluasi, dan Revisi)}

Pada tahap ini produk yang telah dibuat atau didesain akan dievaluasi. Tahap evaluasi ini produk akan di validasi oleh validator pada tahap Expert Review. Expert Review adalah teknik untuk memperoleh masukan atau saran dari para ahli untuk penyempurnaan instrumen tes. Pada tahap uji coba pakar (expert review) disini atau biasanya disebut uji validitas, produk yang telah didesain akan dicermati, dinilai dan dievaluasi oleh pakar atau ahli. Para pakar atau validator akan menelaah konten, konstruks dan bahasa dari masing-masing prototype. Validator pada penelitian ini terdiri dari tiga orang yaitu dua dosen pendidikan matematika dan satu guru bidang studi matematika di tempat uji coba yang kemudian memberikan penilaian berdasarkan instrumen yang diberikan oleh peneliti.

Pada tahap ini, tanggapan dan saran dari para validator tentang desain yang telah dibuat ditulis pada lembar validasi sebagai bahan merevisi dan menyatakan bahwa instrumen tes kemampuan berpikir tingkat tinggi tersebut telah valid. Instrumen yang digunakan yaitu angket validasi berikut kisi-kisi instrumen yang akan digunakan: 
Tabel 2. Kisi-Kisi Instrumen untuk Ahli/Pakar

\begin{tabular}{|c|c|c|c|}
\hline No & Indikator & Komponenen Penilaian & $\begin{array}{c}\text { Jumlah } \\
\text { Butir }\end{array}$ \\
\hline \multirow[t]{4}{*}{1} & \multirow[t]{4}{*}{ Materi } & Kesesuaian SK, KD, dan Indikator. & 1 \\
\hline & & $\begin{array}{l}\text { Batasan pertanyaan dan jawaban yang diharapkan } \\
\text { sesuai dengan jenjang dan jenis pendidikan. }\end{array}$ & 1 \\
\hline & & $\begin{array}{l}\text { Isi materi yang ditanyakan sesuai dengan jenjang } \\
\text { dan jenis penelitian. }\end{array}$ & 1 \\
\hline & & Kesesuaian isi materi dengan pola bilangan & 1 \\
\hline \multirow[t]{5}{*}{2} & \multirow[t]{5}{*}{ Konstruksi } & $\begin{array}{l}\text { Rumusan kalimat dalam bentuk kalimat tanya atau } \\
\text { perintah yang memuat jawaban terurai }\end{array}$ & 1 \\
\hline & & $\begin{array}{l}\text { Kesesuaian petunjuk yang jelas cara } \\
\text { mengerjakan/menyelesaikan soal. }\end{array}$ & 1 \\
\hline & & Kesesuaian pedoman penskrorannya. & 1 \\
\hline & & $\begin{array}{l}\text { Kesesuaian tabel, grafik, diagram, kasus atau } \\
\text { sejenisnya dengan masalah yang ditanyakan. }\end{array}$ & 1 \\
\hline & & $\begin{array}{l}\text { Butir soal tidak tergantung pada jawaban soal } \\
\text { sebelumnya }\end{array}$ & 1 \\
\hline \multirow[t]{4}{*}{3} & \multirow[t]{4}{*}{ Bahasa } & Rumusan kalimat komunikatif & 1 \\
\hline & & Kalimat menggunakan bahasa yang baik dan benar & 1 \\
\hline & & $\begin{array}{l}\text { Rumusan kalimat tidak menimbulkan penafsiran } \\
\text { ganda }\end{array}$ & 1 \\
\hline & & $\begin{array}{l}\text { Rumusan butir soal tidak mengandung kata-kata } \\
\text { yang dapat menyinggung perasaan peserta didik }\end{array}$ & 1 \\
\hline
\end{tabular}

Teknik analisis data menggunakan uji kelayakan, soal Tes HOTS di berikan kepada tiga orang validator yaitu dua dosen pendidikan matematika dan satu guru bidang studi matematika di tempat uji coba yang kemudian memberikan penilaian kelayakan berdasarkan instrumen yang diberikan oleh peneliti. Dengan menggunakan rumus sebagai berikut:

$$
K=\frac{\sum_{j=1}^{m} \bar{x}}{m}
$$

Keterangan:

$K=$ Validitas Soal tes HOTS

$\bar{x}_{1}=$ rerata hasil penilaian item ke- $\mathrm{j}$

$m=$ banyak item 
Kelayakan soal tes HOTS menggunakan kriteria pada tabel berikut :

Tabel 3.Kriteria Kelayakan Soal Tes HOTS

\begin{tabular}{cc}
\hline Nilai Kelayakan $(\%)$ & Kriteria \\
\hline $\mathrm{R}>3,20$ & Sangat Valid \\
$2,40<\mathrm{R} \leq 3,20$ & Valid \\
$1,60<\mathrm{R} \leq 2,40$ & Cukup Valid \\
$0,80<\mathrm{R} \leq 1,60$ & Kurang Valid \\
$\mathrm{R} \leq 0,80$ & Tidak Valid \\
\hline
\end{tabular}

Kelayakan soal tes HOTS yang dikembangkan dilihat berdasarkan tabel kriteria kelayakan soal tes HOTS di atas, soal tes HOTS dikatakan layak apabila skor pada kriteria kelayakan melebihi 2,40.

\section{HASIL DAN PEMBAHASAN}

Pada penelitian ini mengikuti langkah-langkah pada tahapan-tahapan pengembangan yang telah ditentukan pada bab sebelumnya.

\section{Tahap Preliminary}

Tahapan ini dimulai dengan pengkajian terhadap masalah di sekolah menengah pertama kemudian pengumpulan beberapa referensi yang berhubungan dengan penelitian ini, yakni tentang pengembangan soal HOTS materi bilangan di sekolah menengah pertama. Dari referensi-referensi tersebut diperoleh beberapa teori-teori yang telah dikemukakan oleh para ahli dan berhubungan dengan penelitian ini. Salah satu dari teori tersebut adalah kemampuan berfikir tingkat tinggi menurut Taksonomi Bloom teori tersebut menjelaskan bahwa kemampuan berpikir tingkat tinggi diklasifikasikan pada 3 ranah kognitif, yaitu analisis, evaluasi, dan mengkreasi.

\section{Tahap Self Evaluation}

Tahap ini bertujuan untuk merancang sebuah instrumen tes kemampuan berpikir tingkat tinggi yang berdasarkan pada hasil tahap preliminary, instrumen tes yang akan dirancang terdiri dari kisi-kisi tes, soal tes, dan kunci jawaban tes. Pada tahap ini ada 2 kegiatan, yaitu analisis dan desain. 


\section{Analisis}

Tahap analisis ini terdiri dari analisis kurikulum, analisis peserta didik, dan analisis materi.

\section{Analisis Kurikulum}

Kegiatan analisis kurikulum dilakukan untuk memeriksa kesesuaian dari tujuan pembelajaran, cakupan materi dan strategi yang diperlukan dalam pengembangan tes agar dapat mengukur kemampuan berpikir tingkat tinggi pada peserta didik. Pengembangan ini mengacu pada kurikulum 2013, kurikulum 2013 bertujuan untuk meningkatkan kemampuan berpikir tingkat tinggi peserta didik yang berorientasi pada karakteristik kompetensi yang mencakup sikap, keterampilan dan pengetahuan.

Pembelajaran pada kurikulum juga menggunakan pendekatan scientific approach (pendekatan saintifik). Pembelajaran dalam pendekatan saintifik bertujuan untuk meningkatkan kemampuan berfikir tingkat tinggi. Berdasarkan wawancara dengan guru mata pelajaran matematika SMP Negeri 1 Kota Bengkulu diketahui bahwa kurukulum 2013 sudah diterapkan.

\section{Analisis Peserta didik}

Kegiatan analisis peserta didik difokuskan pada peserta didik kelas VIII sebagai subjek uji coba karena peserta didik kelas VIII telah menerima materi pelajaran. Rata-rata jumlah peserta didik pada masing-masing kelas adalah 36 peserta didik. Berdasarkan hasil observasi dan wawancara dari guru matematika, diketahui bahwa pengetahuan matematika kelas VIII SMP Negeri 1 Kota Bengkulu bervariasi. Ada yang berkemampuan tinggi, sedang dan rendah. Hal ini memungkinkan adanya faktor dari minat yang dimiliki setiap peserta didik berbedabeda terhadap pelajaran matematika.

\section{Analisis Materi}

Analisis materi merupakan kegiatan mengidentifikasi konsep-konsep utama yang akan digunakan dalam tes pada materi matematika kelas VIII SMP. Berdasarkan kegiatan analisis kurikulum dan observasi di SMP Negeri 1 Kota Bengkulu, didapatkan bahwa materi yang akan digunakan dalam pengembangan soal HOTS adalah materi pada kurikulum 2013 untuk mata pelajaran matematika kelas VIII materi pola bilangan. 


\section{Desain}

Setelah kegiatan analisis materi dilakukan tahapan selanjutnya adalah merancang instrumen paket tes kemampuan berpikir tingkat tinggi, meliputi kisi-kisi tes, soal tes dan kunci jawaban. Tahapan awal yang dilakukan peneliti adalah merancang soal tes kemampuan berpikir tingkat tinggi. Soal-soal dirancang berdasarkan indikator kemampuan berpikir tingkat tinggi. Peneliti merancang beberapa butir soal yang mewakili masing-masing materi yaitu pola bilangan. Soal tersebut merupakan soal uraian yang memiliki kriteria sebagai soal kemampuan berpikir tingkat tinggi.

\section{Tahapan Prototyping}

Tujuan dari tahap prototyping ini adalah untuk menghasilkan Prototype 2 dari soal tes HOTS yang telah direvisi berdasrkan masukan dari para ahli (expert review). Kegiatan pada tahap ini meliputi validasi perangkat oleh validator diikuti dengan revisi. Hasil kegiatan tahap prototyping ini dijelaskan sebagai berikut.

\section{Expert review}

Expert review (penilaian para ahli) digunakan sebagai dasar melakukan revisi dan penyempurnaan prototype. Validasi instrumen dilakukan dengan cara memberikan lembar validasi instrumen kisi-kisi tes, soal tes, dan kunci jawaban tes terhadap validator, yang terdiri atas dua dosen matematika IAIN Bengkulu dan satu orang guru matematika di SMP Negeri 1 Kota Bengkulu. Tahap validasi ini, validator menilai 10 soal yang berkaitan dengan instrumen yang telah dirancang (prototype 1).

Setiap soal memiliki nilai maksimal 4 dan minimal 1. Berdasarkan penilaian validator didapat penilaian secara umun sebagai berikut:

1. Validator 1 menyatakan soal tes HOTS tergolong baik dan dapat digunakan dengan sedikit revisi.

2. Validator 2 menyatakan soal tes HOTS tergolong baik dan dapat digunakan dengan sedikit revisi.

3. Validator 3 menyatakan soal tes HOTS tergolong baik dan dapat digunakan dengan sedikit revisi. 
Saran revisi validator terhadap instrumen yang meliputi kisi-kisi tes, soal tes, dan kunci jawaban tes dapat dilihat pada tabel 4 berikut.

Tabel 4. Saran Revisi dari Validator

\begin{tabular}{|c|c|c|c|}
\hline No & Validator & Instrumen & Saran \\
\hline 1 & $\begin{array}{l}\text { Validator } 1 \\
\text { Mela Aziza, M. Sc }\end{array}$ & $\begin{array}{l}\text { Kisi-kisi } \\
\text { soal tes } \\
\text { Soal Tes } \\
\text { Kunci } \\
\text { Jawaban }\end{array}$ & $\begin{array}{l}\text { Kompetensi dasar sesuaikan dengan } \\
\text { indikator soal } \\
\text { Perbaiki soal no } 8 \text {, dan no } 9 \\
\text { Buat kunci jawaban dengan } 2 \text { cara }\end{array}$ \\
\hline 2 & $\begin{array}{l}\text { Validator } 2 \\
\text { Fatrima Santri Syafri, } \\
\text { M. Pd. Mat }\end{array}$ & Soal Tes & Perbaiki kalimat soal no 4 dan no 7 \\
\hline 3 & $\begin{array}{l}\text { Validator } 3 \\
\text { Haryono, S. Pd }\end{array}$ & $\begin{array}{l}\text { Soal Tes } \\
\text { Kunci } \\
\text { Jawaban }\end{array}$ & $\begin{array}{l}\text { Perjelas petunjuk pengerjaan soal } \\
\text { Perbaiki kunci jawaban no } 9\end{array}$ \\
\hline
\end{tabular}

Berdasarkan tabel 4, komentar dan saran dari validator tersebut digunakan sebagai bahan pertimbangan untuk revisi prototype instrumen tes HOTS. Validator atau ahli diminta untuk memberikan penilaian terhadap semua instrumen tes yang dikembangkan pada prototype 1 yang memuat materi, konstruksi dan bahasa yang ada dalam instrumen.

Setelah dilakukan analisis pada lembar hasil validasi oleh 3 ahli, maka hasil validasi instrumen yang diperoleh adalah rerata total dari semua aspek $(R)$ beserta implementasinya. Analisis validasi instrumen yaitu sebagai berikut.

Tabel 5. Hasil Validasi Para Ahli

\begin{tabular}{cccccc}
\hline $\begin{array}{c}\text { Butir } \\
\text { Soal }\end{array}$ & Validator 1 & Validator 2 & Validator 3 & Rerata & $R$ \\
\hline 1 & 3,92 & 3,92 & 3,84 & 3,89 & 3,73 \\
2 & 3,92 & 3,92 & 3,53 & 3,79 & \\
3 & 3,76 & 3,76 & 3,76 & 3,76 & \\
4 & 3,53 & 3,84 & 3,84 & 3,73 & \\
5 & 3,84 & 3,61 & 3,84 & 3,76 & \\
6 & 3,92 & 3,84 & 3,76 & 3,84 & \\
7 & 3,92 & 3,61 & 3,30 & 3,61 & \\
8 & 3,76 & 3,53 & 3,61 & 3,63 & \\
9 & 3,69 & 3,69 & 3,53 & 3,63 & \\
10 & 3,84 & 3,53 & 3,76 & 3,71 & \\
\hline
\end{tabular}


Dari tabel di atas terlihat bahwa setiap butir soal memiliki nilai rerata yang tinggi dan dari semua memiliki nilai $R$ (validitas soal) sebesar 3,73. Selanjutnya nilai ini diinterpretasikan dalam tabel kriteria kelayakan soal Tes HOTS. Kelayakan soal tes HOTS dikatakan layak apabila skor pada kriteria kelayakan melebihi 2,40. Berdasarkan hasil validasi dari 3 orang validator ahli matematika diperoleh nilai sebesar 3,73 yang berarti soal tes HOTS ini berada pada kriteria sangat valid. Sehingga prototype dapat dikatakan valid. Meskipun prototype dikatakan valid, prototype ini masih perlu direvisi. Revisi ini dilakukan dengan adanya saran yang diberikan oleh para ahli (validator).

\section{KESIMPULAN}

Berdasarkan hasil penelitian dan pembahasan sebelumnya, maka dapat disimpulkan bahwa pengembangan soal HOTS materi bilangan kelas VIII di SMP Negeri 1 Kota Bengkulu yang valid melalui 3 tahapan, yaitu; (1) tahap preliminary, (2) tahap self evaluation (analisis kurikulum, materi, peserta didik) dan desain, (3) tahap prototyping (validasi, evaluasi dan revisi) yang meliputi expert revie. Hasil pengembangan soal HOTS materi bilangan kelas VIII di SMP Negeri 1 Kota Bengkulu diperoleh validitas yaitu berdasarkan hasil validasi dari 3 orang validator diperoleh nilai sebesar 3,73 yang berarti soal tes HOTS ini berada pada kriteria sangat valid.

\section{REKOMENDASI}

Adapun rekomendasi dari penelitian ini adalah perlunya kemampuan awal guru dalam memetakan kemampuan siswa sehingga disesuaikan dengan soal HOTS untuk pengembangan pada materi lainnya.

\section{UCAPAN TERIMAKASIH}

Penulis mengucapkan terima kasih pada pimpinan beserta guru matematika SMP Negeri 1 Kota Bengkulu yang telah mendukung dalam pelaksanaan penelitian ini.

\section{REFERENSI}

Arifin, Z. (2009). Evaluasi Pembelajaran, Bandung: PT. Remaja Rosda Karya.

Badjeber, R., \& Purwaningrum, J. P. (2018). Pengembangan Higher Order thinking Skills dalam pembelajaran matematika di SMP. Guru Tua: Jurnal Pendidikan dan Pembelajaran, 1(1), 36-43. 
Jailani, J., Sugiman, S., \& Apino, E. (2017). Implementing the problem-based learning in order to improve the students' HOTS and characters. Jurnal Riset Pendidikan Matematika, 4(2), 247-259.

Kusumah, Y. S. (2018, May). Enhancing students' mathematical representation and selfefficacy through situation-based learning assisted by geometer's sketchpad program. In Journal of Physics: Conference Series (Vol. 1013, No. 1, p. 012107). IOP Publishing.

Mulyadin, E. (2019, November). Developing of teaching materials for junior high school students based on ethnomathematics on traditional woven cloth (Tembe Nggoli) of Mbojo tribe. In Journal of Physics: Conference Series (Vol. 1280, No. 4, p. 042044). IOP Publishing.

Nursalam, N. (2012). Pengukuran dalam Pendidikan.

Rahayu, T., Purwoko, P., \& Zulkardi, Z. (2008). Pengembangan Instrumen Penilaian dalam Pendidikan Matematika Realistik Indonesia (PMRI) di SMPN 17 Palembang. Jurnal Pendidikan Matematika, 2(2).

Sowanto, S., Andang, A., Mutmainnah, M., \& Saputra, H. A. (2019). Kemampuan SelfEfficacy Mahasiswa Melalui Bahan Ajar Metode Statistika Menggunakan Hybrid Learning Pada Tantangan Revolusi Industri 4.0. Supermat (jurnal pendidikan matematika), 3(2), 65-73.

Tessmer, M. (1993). Planning and conducting formative evaluations: Improving the quality of education and training. Psychology Press.

Wulandari, S., \& Duskri, M. (2020). Pengembangan Soal Higher Order Thinking Skilss (HOTS) pada Materi Aljabar di Sekolah Menengah Pertama (SMP). Jurnal Didaktik Matematika, 7(2), 207-219.

Yokri, V., \& Saltifa, P. (2020). LKPD Matematika Berbasis Inquiry untuk Meningkatkan Kemampuan Pemecahan Masalah Peserta didik SMK Kelas X. Jurnal Equation: Teori dan Penelitian Pendidikan Matematika, 3(1), 76-88. 